\title{
Effect of Humidity of Air on Hydrogen Absorption into Fe with Rust Layer Containing $\mathrm{MgCl}_{2}$ during Atmospheric Corrosion
}

\author{
Yang $\mathrm{WANG}^{1)}$, Jun Yamanishi ${ }^{1)}$ and Takumi HarunA ${ }^{2)^{*}}$ \\ 1) Graduate Student in Graduate School of Science and Engineering, Kansai University \\ 2) Faculty of Chemistry, Materials and Bioengineering, Kansai University
}

Abstract: An Fe plate, whose one side was electro-polished and the other was covered with the rust layer containing $25.7 \mathrm{~g} \cdot \mathrm{m}^{-2} \mathrm{MgCl}_{2}$, was used as the specimen to investigate the effect of humidity on the hydrogen absorption of the plate during atmospheric corrosion. The specimen was subjected to an electrochemical hydrogen-absorption test during which the rusted surface was exposed to the air with controlled relative humidity (RH) and atmospheric corrosion occurred on it. When the rusted surface was subjected to dry (RH 0\%)-wet (RH 27\%) cycle tests for $10.8 \mathrm{ks}$ each, the anodic current density corresponding to the hydrogen-absorption rate was measured on the hydrogen detection surface. The maximum current density was almost independent of the cycle during the first 10 cycles, after which it decreased with an increase in the cycle, reaching almost a steady value after about 40 cycles. After 55 cycles of the dry-wet cycle test, the specimen was subjected to an electrochemical hydrogen-absorption test to obtain the relationship between the steady-state hydrogen-absorption rate and RH. Hydrogen absorption was observed at RH over about $15 \%$, and the absorption rate increased rapidly with an increase in $\mathrm{RH}$, reached a maximum at RH of about $30 \%$, and then decreased rapidly. When RH increased beyond $40 \%$, the absorption rate increased again, reached a maximum value at RH of $80 \%$, and then decreased gradually. The specimen with the rust layer containing $39.8 \mathrm{~g} \cdot \mathrm{m}^{-2} \mathrm{MgCl}_{2}$ also showed two peaks in the hydrogen-absorption rate versus RH plot.

Keywords: hydrogen absorption; iron; rust layer; magnesium chloride; relative humidity.

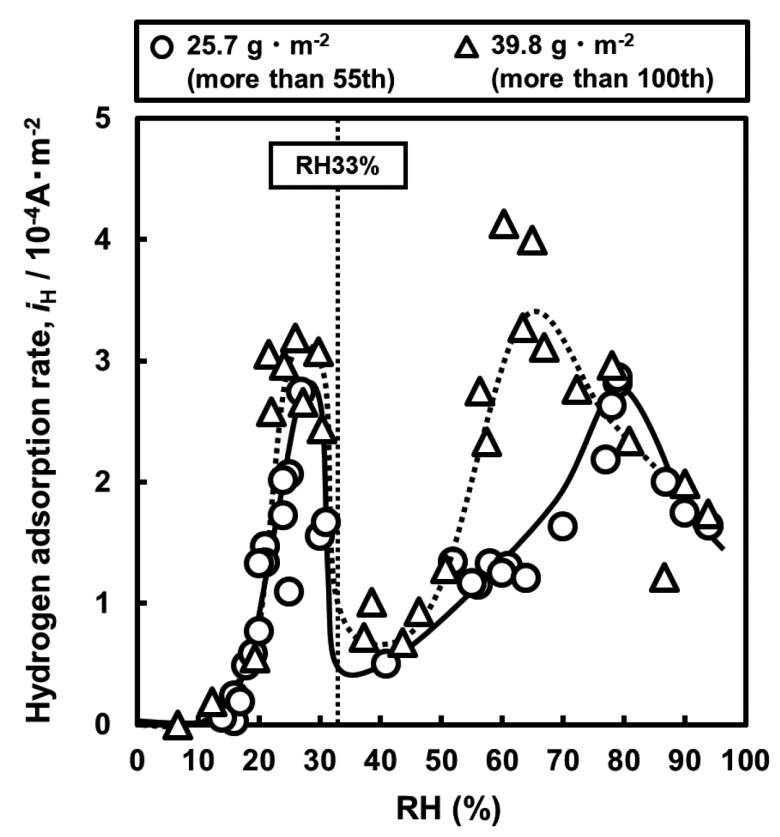

Received on Jul. 17, 2021; Accepted on Jul. 30, 2021; J-STAGE Advance published on Aug. 25, 2021; originally published in ISIJ Int., Vol.61 (2021), No.4, pp.1143-1150 


\title{
$\mathrm{MgCl}_{2}$ を含むさび層を形成させた $\mathrm{Fe}$ の大気腐食に伴う 水素侵入に及ぼす大気湿度の影響
}

\author{
汪 洋 $^{1)} \cdot$ 山西 潤 $^{1)} \cdot$ 春名 匠 $^{2) *}$ \\ Effect of Humidity of Air on Hydrogen Absorption into Fe \\ with Rust Layer Containing $\mathrm{MgCl}_{2}$ during Atmospheric Corrosion \\ Yang Wang, Jun YAmanishi and Takumi Haruna
}

\section{1. 緒言}

近年, 省エネルギー問題や環境保護の観点から超高強度 鋼が要望されており, 現在 $2000 \mathrm{MPa}$ 超える鋼材が開発 されているが，さらなる高強度鋼が期待されている。しか し，高強度鋼を湿潤な大気環境中で使用すると，いわゆる 「遅れ破壊」を起こす場合があることが知られている1)。し たがって，遅れ破壊の原因を究明し，その対策を見出すこ とが急務となっている。これまでの研究では, 遅れ破壊が 水素脆化 (HE) であること ${ }^{2)}$, 水素は鋼材の大気腐食中に 生成し，鋼材中に侵入・拡散すること，0.2\%耐力が 1200 $\mathrm{MPa}$ を超える鋼材はHEを起こしやすいこと ${ }^{3)}$, 強度の高い 鋼材ほど少量の水素の侵入によって HEを発生すること ${ }^{4}$ が報告されている。

これまで行われてきたHEに関する研究の多くは, 多量 の水素が侵入しても高い耐HE性を示す高強度鋼を開発す るために必要な微細構造の制御 ${ }^{5)}$ や鋼中水素の拡散速度の 把握 ${ }^{6}$ に焦点を当てていた。一方, 鋼材への水素侵入に焦 点を当てた研究例はそれほど多くない。そのような背景か ら，2013年から日本鉄鋼協会に「革新的水素不働態表面構 築の原理探求」研究会が設置され, 鋼材への水素侵入に関 する多くの基礎的な情報が蓄積された ${ }^{7)}$ 。例えば, 電気化 学的水素透過試験に抏いて, 鋼材の水素侵入側表面におけ る水素濃度は, その表面の環境条件が急変しても比較的短 時間で定常值を示すこと, 水素濃度の対数は鋼材の硬度の 増加とともに直線的に増加すること, 水素濃度の対数は鋼 材水素の拡散係数の逆数の増加とともに直線的に増加す ること, 水素濃度はカソード電位の上昇とともに減少する が，アノード電位の上昇とともにわずかに増加すること ${ }^{8,9)}$ などが明らかにされた。この研究グループの多くは, 鋼材
の水素侵入面に試験溶液を接触させた状態で電気化学的 水素透過試験を実施し, カソード反応速度や溶液条件など の電気化学的要因の観点から鋼材への水素侵入機構を検 討した。一方, 現実に起こる高強度鋼のHEは湿潤大気中 での腐食に伴って発生することが多いので, その発生機構 を理解するためには, HEに及ぼす大気環境因子の影響を 整理することが必要である。Akiyama ${ }^{10)}$ は, 中国の北京, 重慶および日本の沖縄で大気に曝露された Fe試料への電 気化学的水素透過試験を行い, 最大水素透過速度と大気污 染物質との関係について検討した。Tsuru ${ }^{11)}$ は, Fe板に $\mathrm{Na}_{2} \mathrm{SO}_{3}$ 水溶液の液滴を付着させ, 液滴の乾燥中に起こる大 気腐食に伴う水素透過速度を計測し, $\mathrm{Na}_{2} \mathrm{SO}_{3}$ が $\mathrm{pH}$ と腐食 電位を低下させ，水素侵入を促進させることを明らかにし た。Tada and Miura ${ }^{12)} お よ ひ ゙ S a k a i r i ~ a n d ~ T a k a g i{ }^{13)}$ は, NaClお よび $\mathrm{Na}_{2} \mathrm{SO}_{4}$ 水溶液を滴下し $\mathrm{Zn}$ めっき鋼に乾湿繰り返し腐 食試験を実施している間の水素透過速度を連続的に計測 し, Znめっき鋼が局部的に破壊されたときに水素侵入が 起こることを明らかにした。これらをはじめとする水素侵 入に関する研究の多くは, 十分な研磨が行われた鋼材表面 への水素侵入に焦点を当てていた。しかし, 高強度鋼の HE は, 大気腐食が起こりその表面にさび層が形成した状況で 起こることが想定されるので, 表面にさび層が形成された 鋼材への大気腐食中の水素侵入挙動を理解することは非常 に重要である。そこで, 著者らの研究グループは, さび層 を形成させた Fe板に湿度を制御した大気を接触させて, 大 気腐食中の水素透過速度を連続的に計測するシステムを開 発し, $\mathrm{NaCl}$ を含むさび層を形成した $\mathrm{Fe}$ 板の大気腐食中に 計測される水素透過速度と室内の相対湿度 (RH) との関係 について調べ ${ }^{14)}$, RHが $42 \%$ から 95\%の間で水素侵入が起 こること, 約 $75 \%$ の RHで水素侵入が最大になること, 検

原著論文 : ISIJ Int., Vol.61 (2021), No.4, pp.1143-1150

2021 年7月17日受付 2021年7月30日受理２021年8月25日J-STAGE早期公開 (Received on Jul. 17, 2021; Accepted on Jul. 30, 2021; J-STAGE Advance published on Aug. 25, 2021; originally published in ISIJ Int., Vol.61 (2021), No.4, pp.1143-1150)

1) 関西大学大学院理工学研究科 (Graduate Student in Graduate School of Science and Engineering, Kansai University)

2) 関西大学化学生命工学部 (Faculty of Chemistry, Materials and Bioengineering, Kansai University)

* Corresponding author.E-mail: haruna@kansai-u.ac.jp, Address: Kansai University, 3-3-35 Yamate-cho Suita Osaka 564-8680 
討した RHの範囲で大気腐食を起こしたときのさび層の $\mathrm{pH}$ は弱酸性である4.2〜 4.3 と推定されることを明らかにし た ${ }^{15,16)}$ 。本研究では先行研究 ${ }^{14)}$ を拡張し, $\mathrm{MgCl}_{2}$ 水溶液を 接触させて表面にさび層を形成させた $\mathrm{Fe}$ 板の大気腐食に 伴う水素侵入に及ぼすRHの影響を検討した。

\section{2. 実験方法}

\section{$2 \cdot 1$ 試料作製}

供試材である厚さ $2 \mathrm{~mm}$ の $\mathrm{Fe}$ 板（純度 $99.5 \mathrm{mass} \%$ ）を 40 $\mathrm{mm} \times 40 \mathrm{~mm}$ に切断し, 残留応力を除去するために 1037 $\mathrm{K} \times 1.8 \mathrm{ks}$ の焼鈍を行い, その後炉冷した。この試料はほ ぼ等軸粒で構成され，切片法によって求めた平均粒径は 約 $0.69 \mathrm{~mm}$ であった。この試料の焼鈍に伴う酸化皮膜を除 去するために表面に $\# 6 / 0$ （\#800に相当）までの機械研磨を 行った後, 表面の加工層を除去するために電解研磨を行っ た。反応槽には $\mathrm{Pt}$ 対極と $\mathrm{Ag} / \mathrm{AgCl}$ (飽和 $\mathrm{KCl}$, 室温) を設 置し, 試料を含めてポテンショスタット（東方技研製PS07)に接続した。 $\mathrm{H}_{3} \mathrm{PO}_{4}$ (濃度 : 85 mass\%) と $\mathrm{H}_{2} \mathrm{SO}_{4}$ (濃度 : 95 mass\%）をそれぞれ 75 vol\%と 25 vol\%で混合した溶液 を反応槽に注入した後に, 試料に $1.5 \mathrm{~V}_{\mathrm{Ag} / \mathrm{AgCl}}$ を $84.6 \mathrm{ks}$ 印加 した。この電解研磨で溶解した試料の表面厚さは約 $50 \mu \mathrm{m}$ であった。その後, 試料の片面を polytetrafluoroethylene製
テープで完全に覆い，他面にNiめっきを行った。ポテンシ オスタットに接続した試料とPt対極を設置した反応槽に Watt浴 $\left(\mathrm{NiSO}_{4} \cdot 6 \mathrm{H}_{2} \mathrm{O}: 250 \mathrm{~kg} \cdot \mathrm{m}^{-3}, \mathrm{NiCl} \cdot 6 \mathrm{H}_{2} \mathrm{O}: 45 \mathrm{~kg} \cdot \mathrm{m}^{-3}\right.$, $\mathrm{H}_{3} \mathrm{BO}_{3}: 40 \mathrm{~kg} \cdot \mathrm{m}^{-3}$ ) を注入し, $333 \mathrm{~K} に$ 保持した後に一 10 $\mathrm{A} \cdot \mathrm{m}^{-2}$ の電流密度を $420 \mathrm{~s}$ 印加した。この手順で試料に形 成したNiめっき厚さは約 $15 \mathrm{~nm}$ とされている ${ }^{17,18)}$ 。

\section{$2 \cdot 2$ さび層の形成方法}

Niめっき層を形成していない試料表面には，以下の手 順でさび層を形成させた。表面にOリング（内径 $31 \mathrm{~mm}$ ) を固定し，穴の内側に $0.1 \mathrm{kmol} \cdot \mathrm{m}^{-3} \mathrm{MgCl}_{2}$ 水溶液を $2.0 \times$ $10^{-6} \mathrm{~m}^{3}$ 注入した後に, シリカゲルを入れた密閉容器内で $86.4 \mathrm{ks}$ 乾燥させてさび層を発生させた。そのさび層に純水 を $2.0 \times 10^{-6} \mathrm{~m}^{3}$ 滴下して同じ方法で乾燥させた。再度純 水を滴下し乾燥させることによって, 表面に均一なさび層 を形成させた。さび層に含まれる $\mathrm{MgCl}_{2}$ (無水物) は2 25.7 $\mathrm{g} \cdot \mathrm{m}^{-2}$ と算出された。また, $39.8 \mathrm{~g} \cdot \mathrm{m}^{-2}$ の $\mathrm{MgCl}_{2}$ を含むさび 層を形成した試料を, $0.1 \mathrm{kmol} \cdot \mathrm{m}^{-3} \mathrm{MgCl}_{2}$ 水溶液を $3.0 \times$ $10^{-6} \mathrm{~m}^{3}$ 使用して同様に作製した。

\section{$2 \cdot 3$ 電気化学的水素透過試験およびその他の試験}

電気化学的水素透過試験では, 改良型の DevanathanStachursky型セル ${ }^{19)}$ を採用した ${ }^{14)}$ 。試験装置の概略図を Fig.1に示す。RH $5 \%$ 以下の乾燥した大気で満たされた箱

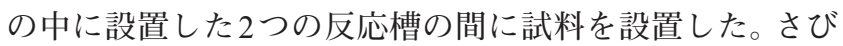

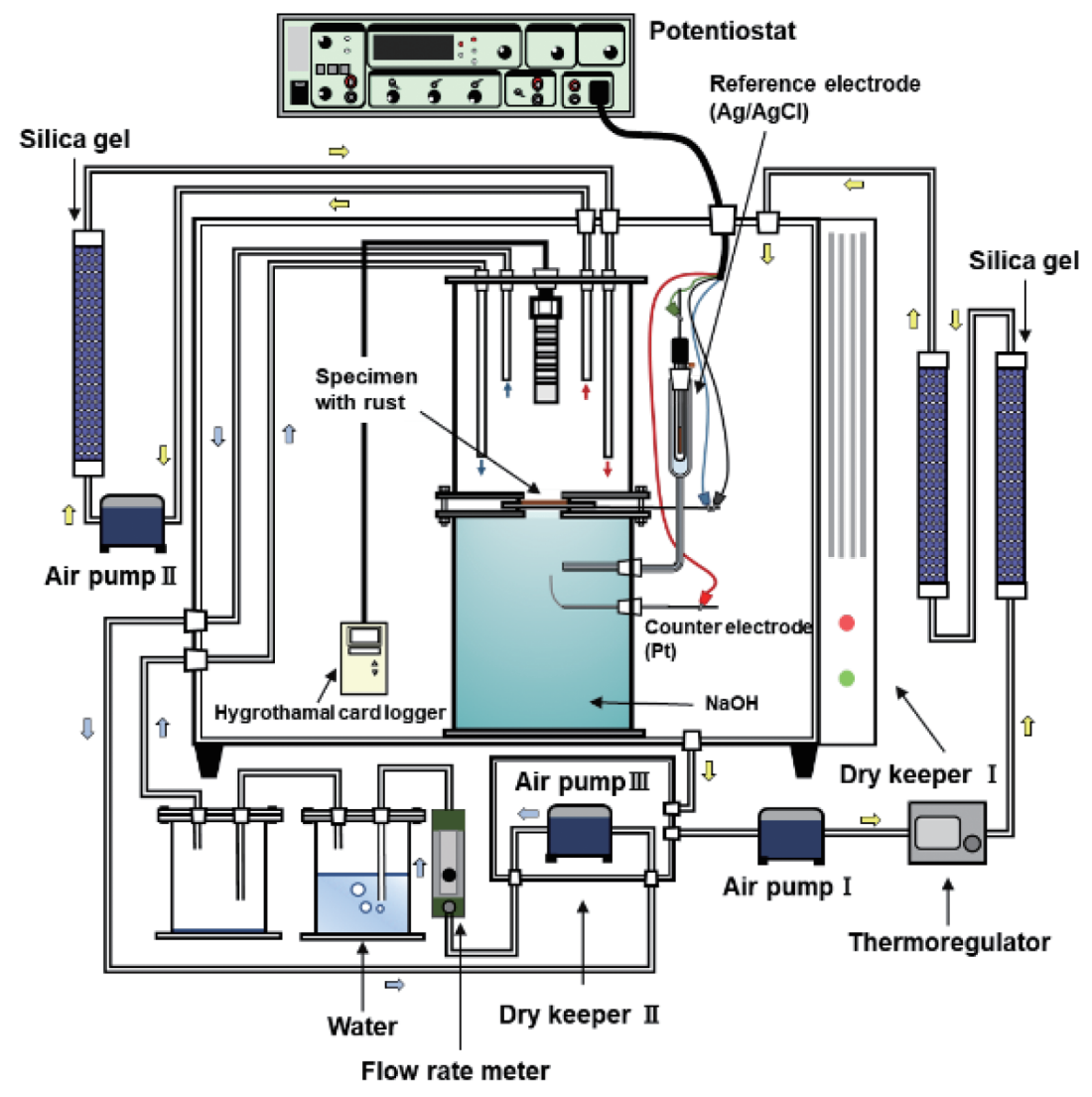

Fig. 1. Schematic illustration of a system for electrochemical hydrogen absorption test in atmospheric corrosion under controlled relative humidity (RH) and temperature. (Online version in color.) 
層面に接している水素侵入用反応槽にはRHを制御した大 気を導入した。一方，Niめっき面に接している水素検出用 反応槽には $0.1 \mathrm{kmol} \cdot \mathrm{m}^{-3} \mathrm{NaOH}$ 水溶液を導入した。後者の 反応槽には, $\mathrm{Ag} / \mathrm{AgCl}$ 参照電極と $\mathrm{Pt}$ 対極を設置し, 試料と ともにポテンショスタットに接続した。操作手順はつぎの 通りである。試料を2つの反応槽の間に設置し，水素検出 用反応槽に $\mathrm{RH} 0 \%$ の乾燥空気を導入した。一方，水素検出 用反応槽に $\mathrm{NaOH}$ 水溶液を導入し, $\mathrm{Ni}$ めっき面に不働態化 電位である $0 \mathrm{~V}_{\mathrm{Ag} / \mathrm{AgCl}}$ を印加した。不働態化電流密度が 0.2 $\mathrm{mA} \cdot \mathrm{m}^{-2} に$ 到達した後に, つぎに示す手順に従って,さび 層面に乾湿繰り返し試験を行った。 $25.8 \mathrm{~g} \cdot \mathrm{m}^{-2}$ の $\mathrm{MgCl}_{2}$ を 含むさび層には, 乾燥 $(\mathrm{RH} 0 \%)$ 大気と湿潤 $(\mathrm{RH}$ 約 $27 \%)$ 大

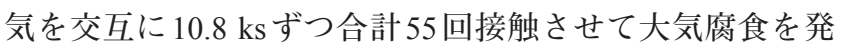
生させた。試験中には, 水素侵入用反応槽内の RH と温度 および水素検出用反応槽のアノード電流密度を同時に計 測した。一方, $39.8 \mathrm{~g} \cdot \mathrm{m}^{-2}$ の $\mathrm{MgCl}_{2}$ を含むさび層には, 乾燥

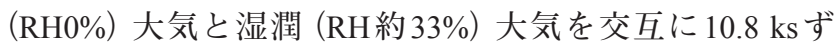
つ合計 100 回接触させた。乾湿繰り返し試験を行った後の 試料には，RHに応じた定常的なアノード電流密度を測定 する試験を行った。まず, $\mathrm{Ni}$ の不働態化電流密度が定常值 に到達するまで，さび層面に乾燥空気を50〜100 ks 接触さ せた後，所定の RHに制御した湿潤空気を接触させた。ア ノード電流密度が定常值に到達した後に，再び乾燥空気を $50 \sim 100 \mathrm{ks}$ 接触させた。この試験から得られた, 湿潤大気 に接触させたときの定常アノード電流密度と乾燥大気に接 触させたときの $\mathrm{Ni}$ 不働態化電流密度の差を, 定常的な水 素透過速度 $i_{\mathrm{H}}$ と定義した。また, さび層の同定にはX線回 折 (XRD) 装置（リガク製RINT-2550）を, 試料表面の観察 にはCCDカメラシステム（モリテックス製MS-804）を，さ び層の形状測定には3D測定システム (キーエンス製VR3200）を，さび層の微細形状の観察には走查型電子顕微鏡 （SEM）（日本電子製JSM-6060LV）を使用した。さび層の形 状測定から得られるさび層の平均厚さは，さび層が形成さ れていない $\mathrm{Fe}$ 板表面を基準とした值である。

\section{3. 結果}

\section{$3 \cdot 1$ 乾湿繰り返し試験中における水素侵入}

$25.8 \mathrm{~g} \cdot \mathrm{m}^{-2}$ の $\mathrm{MgCl}_{2}$ を含むさび層を形成させた試料に乾 燥大気 (RH 0\%, $10.8 \mathrm{ks})$ と湿潤大気 (RH 27\%, $10.8 \mathrm{ks}$ )を 繰り返し接触させた乾湿繰り返し試験中に打ける水素検出 面（Niめっき面）でのアノード電流密度の経時変化を Fig.2 に示す。乾燥状態の水素侵入用反応槽に湿潤大気を導入す るたびにRHの急激な上昇が起こり，約 $3 \mathrm{ks}$ 後に定常值を 示した。また，アノード電流密度は， RHが上昇し始めた約 $2 \mathrm{ks}$ 後に増加し始め, 約 $4 \mathrm{ks}$ 後に定常值を示した。逆に, 乾 燥大気を導入すると RHの急激な低下が起こり, 約 $0.6 \mathrm{ks}$ 後 にRHが $0 \%$ まで低下した。アノード電流密度はRHの低下
とともに減少し, 約 $0.6 \mathrm{ks}$ では最大電流密度の $20 \%$ になり, $10.8 \mathrm{ks}$ まで徐々に減少した。

各湿潤時に打ける最大アノード電流密度と乾湿繰り返 し回数の関係を Fig. 3 に示す。電流密度は, 乾湿を 10 回程 度繰り返してもほとんど変化せず，それ以上繰り返すとほ ぼ直線的に減少したが，40 以上繰り返すとほぼ定常值を示 した。また, 10 回程度の繰り返しの間に電流密度が多少変 動していることが確認された。年の変動は約 $\pm 2 \mathrm{~K} の$ 範囲 での温度変化に対応していると考えられ, Ootsuka ${ }^{20)}$ が, 大気腐食中の水素透過速度を検出するセンサーを開発し, その際，わずかな温度変化で水素透過速度が大きく変化す ることを指摘したことと類似した。一方, Fig.3で確認され た 40 回までの乾湿繰り返し試験中に電流密度が減少した 事象は, 屋外に曝露した鋼材に電気化学的水素透過試験を

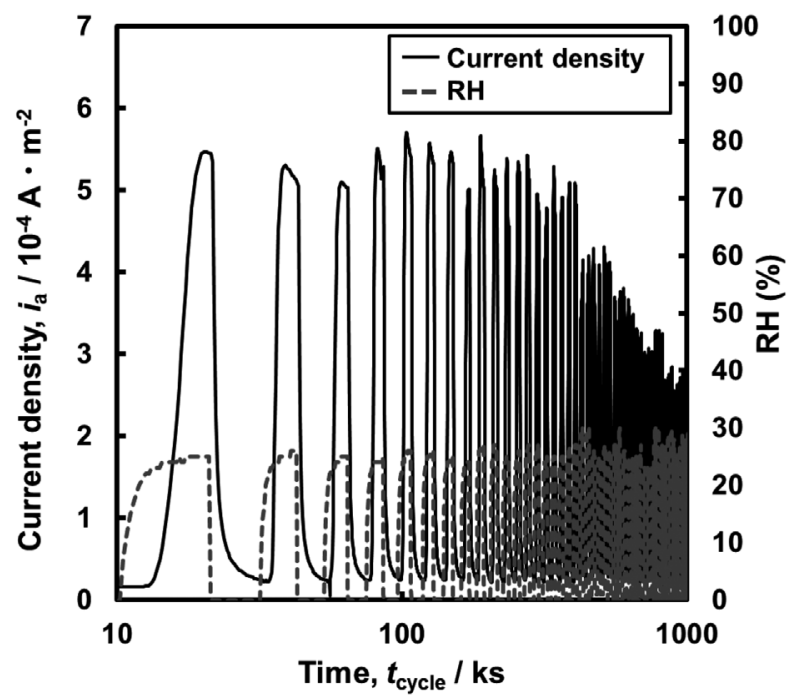

Fig. 2. Changes in RH and anodic current density on hydrogen detection side during the dry-wet (RH c.a. 27\%) cycle test.

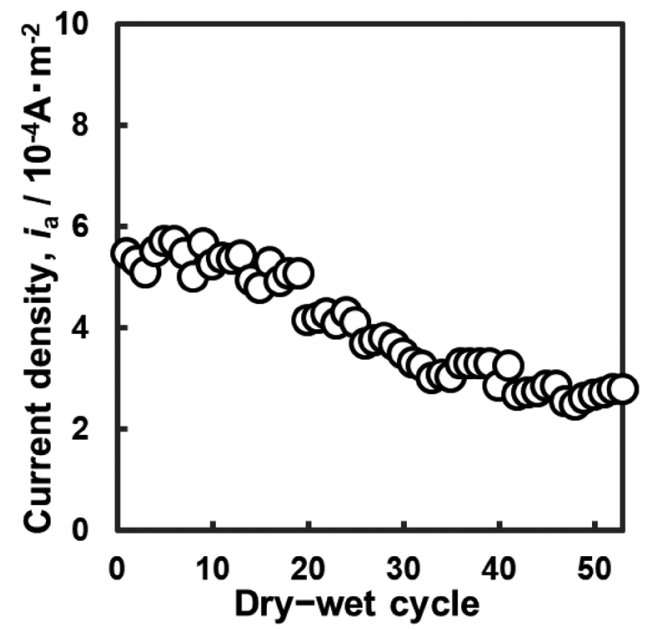

Fig. 3. Change in the maximum anodic current density on hydrogen detection side by 1 cycle during the dry-wet (RH c.a. $27 \%$ ) cycle test. Amount of $\mathrm{MgCl}_{2}: 25.7 \mathrm{~g} \cdot \mathrm{m}^{-2}$ 
行ったときの水素透過速度と累積曝露日数の関係に類似し $た^{21)}$ 。

乾湿繰り返し試験の 10 回目および55回目における試料 の表面から得られたXRDプロファイルを Fig.4に示す。10 回目のさび層には $\alpha-\mathrm{FeOOH}$ が多く, $\mathrm{MgCl}_{2} \cdot 6 \mathrm{H}_{2} \mathrm{O}$ も存在す ることが確認された。また, Feは検出されなかった。一方, 55 回目のさび層には $\beta-\mathrm{FeOOH}, \gamma-\mathrm{FeOOH}, \alpha-\mathrm{FeOOH}$ が多く 含まれており $\mathrm{MgCl}_{2} \cdot 6 \mathrm{H}_{2} \mathrm{O}$ は相対的に減少していた。

乾湿繰り返し試験の 10 回目扎よび55回目における試料 の表面を CCD カメラシステムを用いて観察し，その形状を $3 \mathrm{D}$ 測定システムで測定した結果を Fig. 5 に示す。10回繰り 返した後のさび層は暗褐色でほぼ平坦であり, 平均厚さは 約 $0.05 \mathrm{~mm}$ であった。 55 回繰り返すと, さび層は暗褐色の ままだが凹凸が大きくなり，平均厚さは約 $0.18 \mathrm{~mm}$ になっ た。

Fig.5 (a) および (b) に示したさび層の中心部分に対す るSEM観察結果をFig.6に示す。10回繰り返した後のさび 層を低倍率で観察した場合（Fig.6 (a)) には, Fig.5 (a)で も観察されたように比較的平坦であることに加えて, 多数
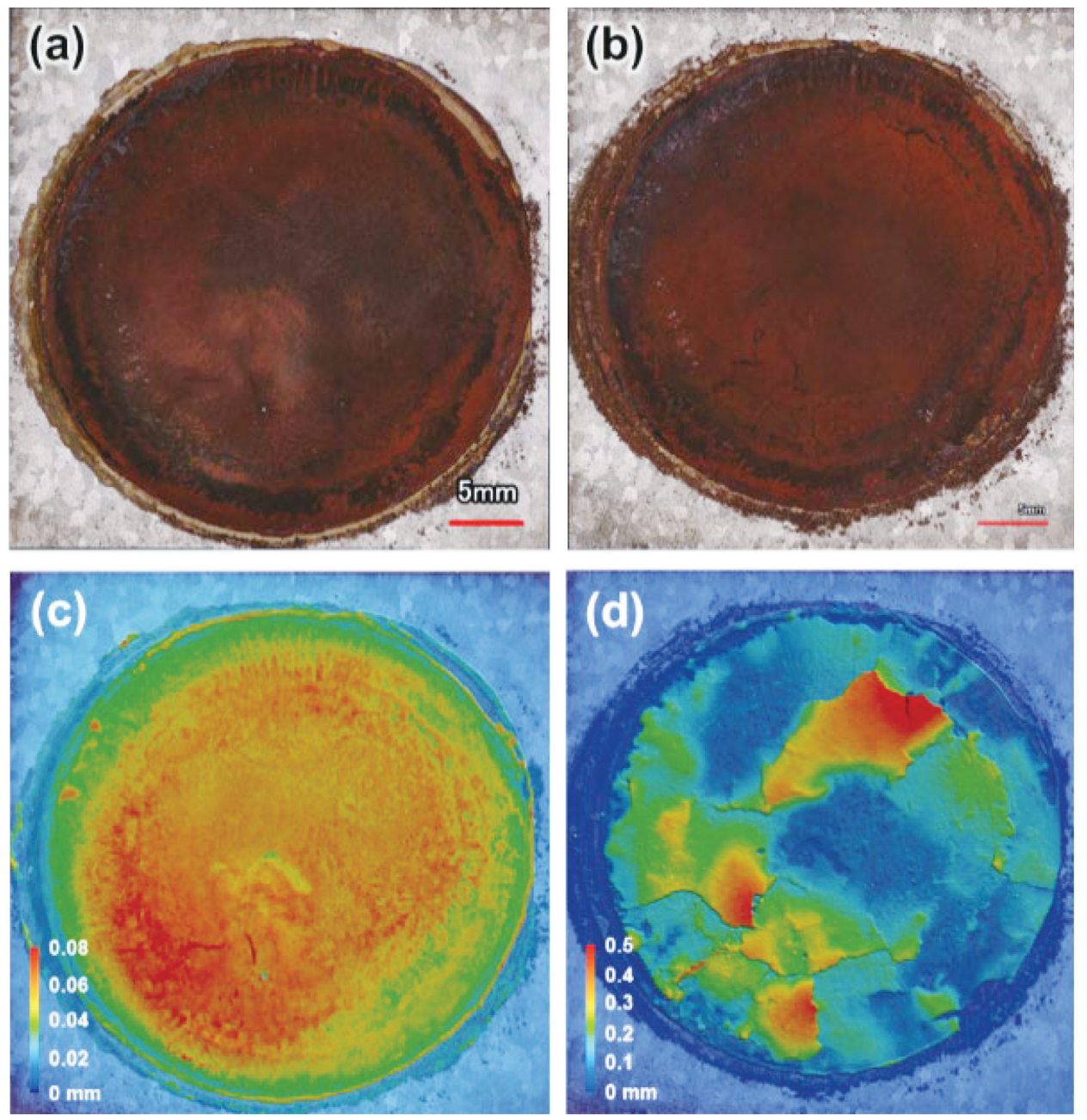

Fig. 5. Surfaces of the specimens covered with the rusts containing $25.7 \mathrm{~g} \cdot \mathrm{m}^{-2} \mathrm{MgCl}_{2}$. observed after (a)(c) 10 and (b)(d) $55 \mathrm{cycles}$ of the dry-wet cycle tests. The images were obtained by (a)(b) the CCD camera system and (c)(d) the 3D-measurement system. 
の小さなブロックで構成されていることがわかり, 高倍率 で観察すると（Fig.6 (e))，このブロックは小さな粒子で構 成されていることがわかった。一方，55回繰り返したさび 層を低倍率で観察すると，10回目より滑らかで平坦になっ ており (Fig.6 (b) ), 高倍率で観察すると, ブロックを構成 している小粒子の平均粒径が約 $3 \mu \mathrm{m}$ に成長していた (Fig.6 (f) )。

\section{$3 \cdot 2$ 乾湿繰り返しを 50 回以上行った試料への水素侵入に 及ぼすRHの影響}

前節で説明したように, $25.7 \mathrm{~g} \cdot \mathrm{m}^{-2}$ の $\mathrm{MgCl}_{2}$ を含むさび 層を形成させた試料に乾湿繰り返し試験を行い, その間に 発生した水素検出面でのアノード電流密度を連続的に測定 した結果, Fig.3に示したように, アノード電流密度 (水素 透過速度に相当）は, 10 回以上乾湿繰り返しを行うと, 回 数の増加とともに減少し，40回以上行うと定常值を示す ことがわかった。そこで, アノード電流密度が乾湿繰り返 し数にほとんど依存しない状態である 40 回以上乾湿繰り 返しを行った試料に対して，所定のRHに制御した大気を さび層に接触させて定常的なアノード電流密度, すなわち
水素透過速度の定常值を測定した。その一例として, 25.7 $\mathrm{g} \cdot \mathrm{m}^{-2}$ の $\mathrm{MgCl}_{2}$ を含むさび層を形成させた試料に乾湿繰り 返しを 55 回行った後に乾燥大気, RH $72 \%$ の湿潤大気, 乾 燥大気をその順番に接触させたときのアノード電流密度の 経時変化を Fig.7 に示す。試験開始時に乾燥空気 (RH 0\%) を水素侵入用反応槽に導入したときの, $\mathrm{Ni}$ の不働態化電 流密度の定常值は $0.040 \times 10^{-4} \mathrm{~A} \cdot \mathrm{m}^{-2}$ であった。湿潤空気 を導入すると, RHは急速に上昇し, 約 $72 \%$ でほぼ定常值 を示した。同時に測定したアノード電流密度は徐々に増加 し, $1.67 \times 10^{-4} \mathrm{~A} \cdot \mathrm{m}^{-2}$ でほぼ定常值を示した。再び乾燥空 気を導入すると, RHは急速に $0 \%$ に低下し, カソード電流 密度は徐々に減少し, 初期值の $0.040 \times 10^{-4} \mathrm{~A} \cdot \mathrm{m}^{-2}$ に到達 した。したがって, RH72\%に打ける水素透過速度 $\left(i_{\mathrm{H}}\right)$ は $1.63 \times 10^{-4} \mathrm{~A} \cdot \mathrm{m}^{-2}$ となった。

同様の方法で得られた種々のRHに対する $i_{\mathrm{H}}$ をまとめて Fig.8に示す。 $i_{\mathrm{H}}$ は $15 \%$ 以上の RHで検出され, RHの増加と ともに急激に増加し, RH $30 \%$ 程度で極大值を示し, その後 は急激に減少した。 $\mathrm{RH}$ が $40 \%$ 以上になると $i_{\mathrm{H}}$ は再び増加 し，RHが約 $80 \%$ で極大值を示し，その後徐々に減少した。
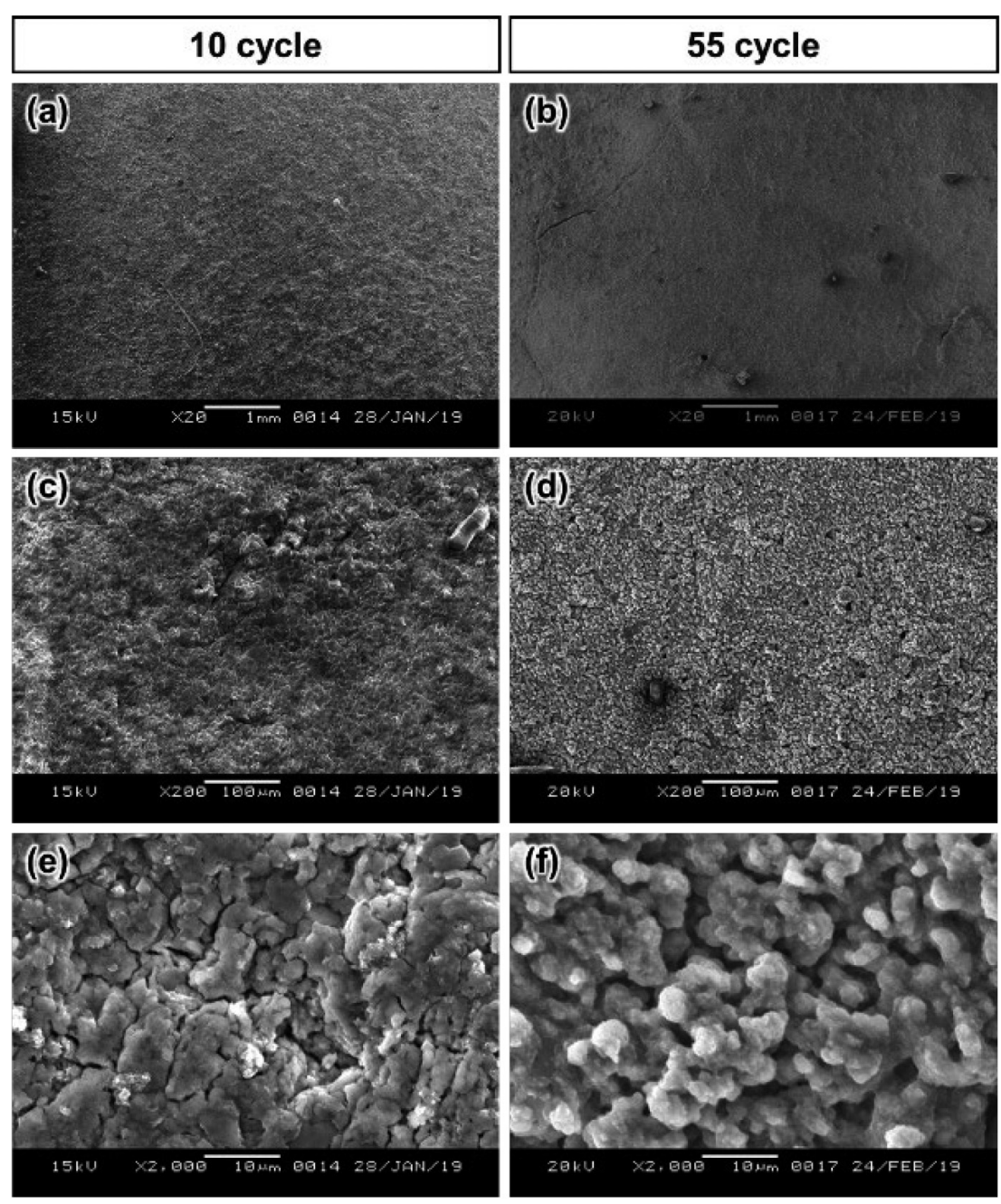

Fig. 6. SEM images for surfaces of the specimens covered with the rust containing $25.7 \mathrm{~g} \cdot \mathrm{m}^{-2} \mathrm{MgCl}_{2}$. (a)(c)(e) 10 cycles and (b)(d)(f) 55 cycles. Magnification: $(a)(b)<(c)(d)<(e)(f)$ 
今後，低 RH領域および高 $\mathrm{RH}$ 領域で観測された $i_{\mathrm{H}}$ のピー クをそれぞれ第 1 ピーク，第2ピークと定義する。さらに， $39.8 \mathrm{~g} \cdot \mathrm{m}^{-2}$ の $\mathrm{MgCl}_{2}$ を含むさび層を形成させた試料に対し て，100回の乾湿繰り返し試験を行った後，種々の RHに対 する $i_{\mathrm{H}}$ を測定した。その結果を Fig.8に重ねて示す。前者の 試料と同様，後者の試料においても RHに対して $i_{\mathrm{H}}$ に $2 つ$ のピークが確認された。また $\mathrm{MgCl}_{2}$ の含有量が多い後者 の試料において，第 1 ピークと第 2 ピークの $i_{\mathrm{H}}$ が大きく，第 1 ピークを示す RHは前者の試料とほとんど同じであった が，第2ピークを示すRHは小さな值を示した。

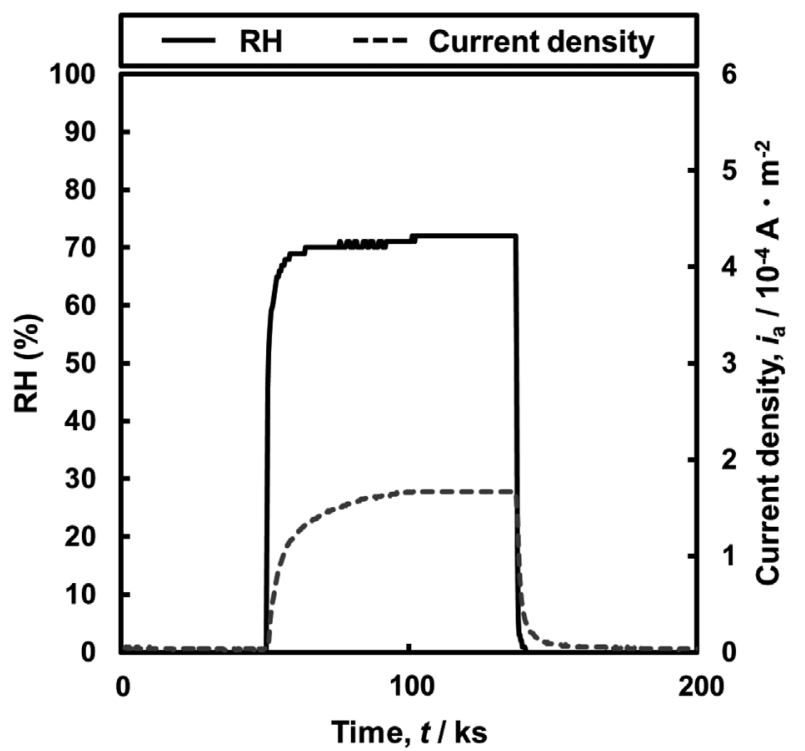

Fig. 7. Typical example of changes in RH and anodic current density on hydrogen detection side with time. Amount of $\mathrm{MgCl}_{2}: 25.7 \mathrm{~g} \cdot \mathrm{m}^{-2}$. Average $\mathrm{RH}$ in the steady state: $72 \%$.

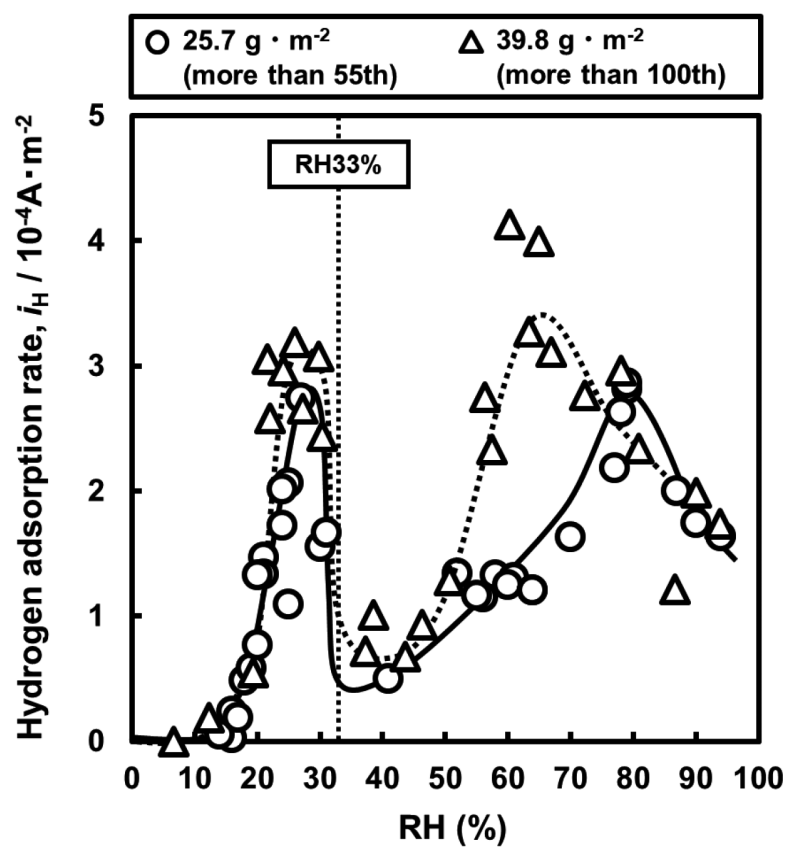

Fig. 8. Effect of RH during wet period on hydrogen absorption rate as a function of amount of $\mathrm{MgCl}_{2}$ in the rust.

\section{4. 考察}

\section{$4 \cdot 1$ 水素透過速度の定常値に及ぼすRHの影響}

25.7 および $39.8 \mathrm{~g} \cdot \mathrm{m}^{-2}$ の $\mathrm{MgCl}_{2}$ を含むさび層を形成させ た試料に 40 回以上の乾湿繰り返しを行った後, 所定の RH の大気を接触させて水素透過速度の定常值 $\left(i_{\mathrm{H}}\right)$ を測定し た結果, Fig.8で説明したように， $i_{\mathrm{H}}$ は $15 \%$ 以上のRHで検 出され, RHの増加とともに急激に増加し, RHが約 $30 \%$ で 第 1 ピークを示し，その後，急激に減少した。RHが $40 \%$ 以 上になると $i_{\mathrm{H}}$ は再び増加し, RHが $65 \sim 80 \%$ のきに第 2 ピークを示し，その後徐々に減少した。このような RHの 変化に伴う $i_{\mathrm{H}}$ の変化の理由を次のように推察した。

一般に $\mathrm{MgCl}_{2}$ の固体は, $\mathrm{RH} 33 \%$ の大気中で潮解 $(298 \mathrm{~K})$ し, 飽和水溶液に変化する。この湿度未満では, 水分子 は $\mathrm{MgCl}_{2}$ 固体の表面にしか吸着しない。すなわち, $\mathrm{RH}$ $33 \%$ 未満の大気中で $\mathrm{Fe}$ 板に $\mathrm{MgCl}_{2}$ 水溶液滴が付着しても, $\mathrm{MgCl}_{2}$ が急速に固体に変化するために, $\mathrm{Fe}$ 板に大気腐食 はほとんど起こらないことになる。いくつかの研究では， $\mathrm{MgCl}_{2}$ 水溶液を用いて, $33 \%$ 以上の $\mathrm{RH}$ 範囲で鋼材の大 気腐食を調査している ${ }^{22,23)}$ 。しかし Fig.8では, RH15\%で大 気腐食による水素侵入が確認されている。一方, 以前の報 告 ${ }^{14)}$ では, $\mathrm{NaCl}$ を含むさび層を形成させた $\mathrm{Fe}$ 板に $\mathrm{RH}$ 制御した大気を接触させた場合の水素侵入挙動を調査し, $\mathrm{NaCl}$ の潮解湿度（RH 75\% at $298 \mathrm{~K}$ ）以下である $40 \%$ 程度の RHで水素侵入が確認されており, さび層に存在する微細 な孔に曲率の小さな飽和 $\mathrm{NaCl}$ 水溶液が毛細管現象で凝縮 して存在することによって腐食を誘発していると説明され ている ${ }^{24)}$ 。本研究で得られた, $\mathrm{MgCl}_{2}$ の潮解湿度よりも低 RHで確認された水素侵入も同様の機構で発現していると 考えられる ${ }^{14)}$ 。 RHの大気中で曲率半径 $r$ の四面を持つ水が 安定の存在するときのRHと $r$ の間にはKelvinの式 ${ }^{25)}$ が成 立する。

$$
\ln \mathrm{RH}=-2 \gamma V_{\mathrm{m}} /(r R T)
$$

ここで, $\gamma$ は水の表面張力, $V_{\mathrm{m}}$ は水のモル体積, $R$ は気 体定数，Tは絶対温度である。この式は，rの小さな水なら RHが小さな大気中でも安定に存在することを示してい る。この関係が，水だけでなく，水溶液にも適用されるな らば，表面が平坦な $\mathrm{MgCl}_{2}$ 飽和水溶液は $\mathrm{RH}$ が $33 \%$ 以下の 大気中では安定に存在することができないが, 表面が凹状 であれば安定に存在する可能性を有する。 $\mathrm{MgCl}_{2}$ 飽和水溶 液に対する式 (1) のいくつかの変数は入手されていないの で, $r$ とRHの定量的な関係を算出することができないが, Fig.8に示すように, RHが 15\%のときに水素透過速度が検 出されているので，このRHにおいてさび層内に存在する $\mathrm{MgCl}_{2}$ の固体が曲率 $r$ の表面を持つ飽和水溶液に潮解した と推察される。このときのカソード反応は, 酸素の還元反 応と考えられる。飽和水溶液中の溶存酸素濃度は非常に小 
さいため, Feに接触している溶液粒子において酸素の拡散 による流束が大きくなる薄い部分で, 式 (2) に従った酸素 の還元反応が起こる。

$$
\mathrm{O}_{2}+2 \mathrm{H}_{2} \mathrm{O}+4 \mathrm{e}^{-} \rightarrow 4 \mathrm{OH}^{-}
$$

RHが $15 \%$ を超えると, $i_{\mathrm{H}}$ はRHの増加とともに増加し， 約 $30 \%$ の RHで第 1 ピークを示し, その後急速に減少した。 この第1ピークの形成をつぎのように推察した。RHが増 加すると, 式 (1) のように溶液の凹面の半径が大きくなる。 この増加は, 溶液の粒子の大きさと数の増加に伴う酸素還 元反応の面積 (溶液粒子の薄部の積算面積) の増加を引き 起こし，そのときの腐食速度の増加に対応した水素侵入に 基づく $i_{\mathrm{H}}$ の増加が観測されると考えられる。 $\mathrm{RH} か ゙ \mathrm{MgCl}_{2}$ の潮解湿度 $(33 \%)$ に近づくと, 飽和水溶液の曲率半径が 急速に無限大に近づく(すなわち溶液表面が平坦になる)。 $\mathrm{Fe}$ 板の表面が飽和水溶液膜でほぼ完全に被覆された場合 には，酸素が液膜を通過して Fe 表面へ供給されなければな らないので, 酸素の供給速度が抑制されることから, 腐食 速度の減少に伴う $i_{\mathrm{H}}$ の減少が観測される。

一方, $\mathrm{RH}$ が $40 \%$ を超えると $i_{\mathrm{H}}$ は再び増加し, $65 \%$ か ら $80 \%$ の RHで第 2 ピークを示し, その後, 徐々に減少 した。この変化をつぎのように推察した。熱力学の観点 からは, 平らな表面を持つ未飽和 $\mathrm{MgCl}_{2}$ 水溶液中の水 の活量は, RH $33 \%$ 以上の大気中に存在する水 (水蒸気) の活量と等しい。この関係は, RHが $33 \%$ 以上に増加す ると, $\mathrm{MgCl}_{2}$ 水溶液中の水の活量が増加することに伴って, 水溶液中の $\mathrm{MgCl}_{2}$ 濃度が減少することを意味している。ま た, 大気中の $\mathrm{RH}$ が変化しても, さび層の $\mathrm{MgCl}_{2}$ 含有量は不 変である。したがって, RHの増加は, 水溶液中の水の量の 増加, 水溶液の体積の増加, 液層の厚さの増加を引き起こ す。 $\mathrm{RH}$ が $33 \%$ 以上で, $\mathrm{Fe}$ 板の表面が $\mathrm{MgCl}_{2}$ 水溶液で被覆 されている場合, 式 (3) に基づく溶存酸素の拡散限界還元 速度が腐食速度 $\left(i_{\text {corr }}\right)$ を決定する。

$$
i_{\text {corr }}=4 F D_{\mathrm{O} 2} C_{\mathrm{O} 2}{ }^{0} / L
$$

ここで, $F$ はファラデー定数, $D_{\mathrm{O} 2}$ は液膜中での酸素の拡 散係数, $C_{\mathrm{O} 2}{ }^{0}$ は液膜の大気側表面の溶存酸素濃度, $L$ は液 膜厚さである。ここで, $\mathrm{RH}$ に依存した液膜の $\mathrm{MgCl}_{2}$ 濃度 の変化に対して $D_{02}$ が影響をほとんど受けない場合を考え る。このとき, $\mathrm{RH}$ が増加すると, $\mathrm{MgCl}_{2}$ 濃度が減少するこ とにより $C_{\mathrm{O} 2}{ }^{0}$ が増加する ${ }^{23)}$ ので, 式 (3)により $i_{\text {corr }}$ が増加 することに伴って $i_{\mathrm{H}}$ が増加することが考えられる。一方, RHが増加すると, $L$ が増加するので, 式 (3) により $i_{\text {corr }}$ が 減少することに伴って $i_{\mathrm{H}}$ が減少することも考えられる。こ の2つの推察を考慮すると, Fig. 8 で確認された第2ピーク の低 $\mathrm{RH}$ 領域における $\mathrm{RH}$ の増加に伴う $i_{\mathrm{H}}$ の増加は, 液膜の $\mathrm{MgCl}_{2}$ 濃度の減少に伴う $C_{\mathrm{O} 2}{ }^{0}$ の增加が主要因であり, 第 2 ピークの高RH領域におけるRHの増加に伴う $i_{\mathrm{H}}$ の減少は,
液膜の体積の増加に伴う $L$ の増加が主要因であると考えら れる。ところで, RHの増加とともに $L$ が増加し, $L$ が拡散 層厚さ $\left(L_{\mathrm{D}}\right.$, 固定值 $)$ を超えると, 式 (3) の $L$ は $L_{\mathrm{D}}$ に置き 換わるが, $C_{\mathrm{O} 2}{ }^{0}$ は增加を続けるので, 式 (3) により, $i_{\text {corr }}$ が 増加することに伴って $i_{\mathrm{H}}$ が増加することが考えられるが, Fig. 8 の高RH領域にはRHの増加に伴う $i_{\mathrm{H}}$ の増加は観測さ れなかった。したがって, 本研究で設定されたRHの範囲 での $L$ は $L_{\mathrm{D}}$ より小さい值であることが示唆された。 $\mathrm{RH}$ $100 \%$ に近づくと, $\mathrm{MgCl}_{2}$ 水溶液の濃度が $0 \mathrm{kmol} \cdot \mathrm{m}^{-3}$ に近 づき, $L$ が無限大に近づく。このとき, $C_{\mathrm{O} 2}{ }^{0}$ は純水に打け る值に近づき, $L$ は $L_{\mathrm{D}}$ を超えるために, $i_{\mathrm{H}}$ は, さび層中の $\mathrm{MgCl}_{2}$ 含有量とは無関係に, 特定の值に収束すると考えら れる。

\section{$4 \cdot 2$ 乾湿繰り返し試験における水素透過速度の变化}

$25.7 \mathrm{~g} \cdot \mathrm{m}^{-2}$ の $\mathrm{MgCl}_{2}$ を含むさび層を形成させた試料に 対して乾湿繰り返し試験（RH 0\%, 10.8 ks 打よびRH27\%, $10.8 \mathrm{ks}$ )を行った結果, Fig.2に示したように, 湿潤大気に 接触させて RHが増加し始めた約 $2 \mathrm{ks}$ 後にアノード電流密 度が増加し始めた。また, 電流密度が増加し始める RHは 15\%程度であることがわかった。また，Fig.8に示したよう に, RHが $15 \%$ 以下の大気に試料を長時間接触させても $i_{\mathrm{H}}$ が検出されなかった。したがって, Fig.2で確認されたRH の増加開始とアノード電流密度の増加開始との間の時間差 は, $\mathrm{RH} か ゙ i_{\mathrm{H}}$ を発生させる値にまで増加する時間であると 考えられる。その後, 乾燥空気を湿潤状態の反応槽に導入 すると, RH とアノード電流密度は短時間でほぼ同時に減 少した。Fig. 8 によと, RHが $27 \%$ であれば十分な $i_{\mathrm{H}}$ が観 測されるが, RHが $15 \%$ 以下になると $i_{\mathrm{H}}$ が観測されないこ とがわかる。そのために, RHと電流密度が同時に急激に 減少したと考えられる。

Fig.3に示したように, 各湿潤状態におけるアノード電流 密度の最大值は, 10 回程度乾湿を繰り返してもほとんど変 化しなかった。しかし, 乾湿繰り返し数がさらに増加する と, 電流密度はほぼ直線的に減少し, 40 回を超えると再び 定常值を示した。さび層の性状をまとめたFigs.4〜7から は, 次のことが理解された。乾湿を 10 回繰り返した後のさ び層は暗褐色で平坦であり, 平均厚さは $0.05 \mathrm{~mm}$ であった。 拡大して観察すると，さび層は小さな粒子で構成されてい た。さび層の表面からは, 豊富な $\alpha-\mathrm{FeOOH} と$ 比較的多い $\mathrm{MgCl}_{2} \cdot 6 \mathrm{H}_{2} \mathrm{O}$ が検出された。一方，乾湿を 55 回繰り返した 後のさび層は暗褐色で比較的大きな凹凸が認められた。ま た，さび層を構成していた小さな粒子は成長しており，さ び層の平均厚さは $0.18 \mathrm{~mm}$ であった。さらに $\alpha-\mathrm{FeOOH}$ に加 えて $\beta$ - $\mathrm{FeOOH}, \gamma-\mathrm{FeOOH}$ も多く検出されたが, $\mathrm{MgCl}_{2} \cdot 6 \mathrm{H}_{2} \mathrm{O}$ は相対的に減少していた。このようなさび層の性状はつ ぎのように水素侵入挙動と関連付けられる。乾湿繰り返 しが多くなると, さび層は厚く, 緻密で比較的成長した小 粒子で構成されていたため, 水素侵入を誘発する大気腐 
食が抑制されたと考えられる。このときのさび層からの $\mathrm{MgCl}_{2} \cdot 6 \mathrm{H}_{2} \mathrm{O}$ 検出量が比較的少なかった理由には, $0.18 \mathrm{~mm}$ の厚さに成長したさび層に $\mathrm{MgCl}_{2} \cdot 6 \mathrm{H}_{2} \mathrm{O}$ 粒子が分散したこ とに加えて, X線の貫入深さである $0.01 \mathrm{~mm}$ 程度より深い さび層内に $\mathrm{MgCl}_{2} \cdot 6 \mathrm{H}_{2} \mathrm{O}$ 粒子が多く存在したことが挙げら れる。また，乾湿繰り返しを多く行ったときのさび層には， $\beta$ - $\mathrm{FeOOH}, \gamma-\mathrm{FeOOH}, \alpha$ - $\mathrm{FeOOH}$ が比較的多く検出された。 ところが，さび層形成の初期段階には $\beta$ - $\mathrm{FeOOH}$ と $\gamma-\mathrm{FeOOH}$ が多く生成されること，これらのさび層は耐食性にそし く, 乾湿繰り返し中に徐々に $\alpha-\mathrm{FeOOH}$ に変化して耐食層を 形成することが知られている ${ }^{26,27)}$ 。本研究で得られた結果 は，報告された知見とは一致しなかった。これは，XRD分 析ではさび層の表面から約 $0.01 \mathrm{~mm}$ までの情報しか得られ ないことが原因であると考えられ，今後は $\mathrm{Fe}$ 基板表面近傍 のさび層に関する情報を入手し検討する必要があることを 示唆する。

\section{5. 結言}

（1） $25.7 \mathrm{~g} \cdot \mathrm{m}^{-2}$ の $\mathrm{MgCl}_{2}$ を含むさび層を形成させた $\mathrm{Fe}$ 板 試料に対して乾湿繰り返し試験 $(\mathrm{RH} 0 \%, 10.8 \mathrm{ks}$ 打よ びRH 27\%, 10.8 ks）を行った。各湿潤状態での最大ア ノード電流密度（水素透過速度に正の相関）は, 乾湿 繰り返しを10回程度行っても変化しなかった。その後 は，回数の増加とともにほぼ直線的に減少し，40回以 上行うと再びほぼ定常值を示した。

（2）乾湿を10回繰り返した後のさび層は暗褐色で平坦で あり，多数の小さな粒子で構成されていた。また，さ び層の平均厚さは $0.05 \mathrm{~mm}$ であり, $\alpha-\mathrm{FeOOH}$ が比較的 多く存在して打り, $\mathrm{MgCl}_{2} \cdot 6 \mathrm{H}_{2} \mathrm{O}$ も検出された。一方, 55 回繰り返した後のさび層は暗褐色のままだが，比較 的大きな凹凸を示していた。さび層を構成する小さな 粒子は成長して打り，さび層の平均厚さは $0.18 \mathrm{~mm} て ゙$ あった。

（3） 25.7 および $39.8 \mathrm{~g} \cdot \mathrm{m}^{-2}$ の $\mathrm{MgCl}_{2}$ を含むさび層を形成さ せた試料に乾湿を 40 回以上繰り返した後に, RHを制 御した大気に接触させて, 定常的な水素透過速度を測 定する電気化学的水素透過試験を行った。その結果, 水素透過速度は $15 \%$ 以上のRHで観測され，RHが $30 \%$ 程度と $65 \%$ ～80\%のときにそれぞれピークを示した。

\section{謝辞}

本研究は，日本鉄鋼協会「革新的水素不働態表面構築の 原理探求」研究会ならびに「鉄鋼材料への腐食誘起水素侵 入」研究会から多数の有益な助言および経済的支援を頂い た。また科学研究費補助金 (基盤研究C)（18K04784）なら びに関西大学学術研究員研究費からも経済的支援を頂い た。ここに謝意を表する。

\section{文献}

1 ) S.Matsuyama: Tetsu-to-Hagané, 80(1994), 679 (in Japanese).

2 ) A.R.Troiano: Hydrogen in Metals, ASM, Metals Park, OH, (1974), 3.

3 ) T.Fujita and Y.Yamada: Stress Corrosion Cracking and Hydrogen Embrittlement of Iron Base Alloys, NACE, Houston, TX, (1977), 736.

4 ) S.Takagi, T.Inoue, K.Tsuzaki and F.Minami: J. Jpn. Inst. Met., 65(2001), 1073 (in Japanese).

5 ) T.Omura: ISIJ Int., 52(2012), 267.

6 ) T.Omura, T.Kushida, T.Kudo, F.Nakasato and S.Watanabe: Zairyoto-Kankyo, 54(2005), 61 (in Japanese).

7 ) M.Sakairi: ISIJ Int., 56(2016), 377.

8 ) T.Haruna, K.Takeuchi, T.Kasahara and Y.Nii: ISIJ Int., 56(2016), 378.

9 ) T.Haruna and Y.Nii: ISIJ Int., 56(2016), 392.

10) E.Akiyama, S.Li, H.Katayama, B.Zhang, K.Zhao and W.Oshikawa: ISIJ Int., 56(2016), 436.

11) T.Tsuru, Y.Huang, M.R.Ali and A.Nishikata: Corros. Sci., 47(2005), 2431.

12) E.Tada and Y.Miura: ISIJ Int., 56(2016), 444.

13) M.Sakairi and S.Takagi: ISIJ Int., 56(2016), 452.

14) T.Haruna, Y.Shoji and Y.Hirohata: ISIJ Int., 61(2021), 1079. https:// doi.org/10.2355/isijinternational.ISIJINT-2020-018

15) E.Akiyama, K.Matsukado, M.Wang and K.Tsuzaki: Corros. Sci., 52(2010), 2758.

16) E.Akiyama, S.Li, T.Shinohara, Z.Zhang and K.Tsuzaki: Electrochim. Acta, 56(2011), 1799.

17) S.Yoshizawa and K.Yamakawa: Boshoku Gijutsu, 24(1975), 365 (in Japanese)

18) S.Yoshizawa, T.Tsuruta and K.Yamakawa: Boshoku Gijutsu, 24(1975), 511 (in Japanese).

19) M.A.V.Devanathan and Z.Stachurski: Proc. R. Soc. A, 270(1962), 90.

20) S.Ootsuka, S.Fujita, E.Tada, A.Nishikata and T.Tsuru: Corros. Sci., 98(2015), 430

21) T.Kushida and T.Omura: Kozozairyo no Kankyo Zeika niokeru Suiso no Kino ni kansuru Kenkyu-5 (Research on Hydrogen Relating Hydrogen Embrittlement to Structural Materials - Part 5), ISIJ, Tokyo, (2003), 101 (in Japanese).

22) Y.Tsutsumi, A.Nishikata and T.Tsuru: J. Electrochem. Soc., 152(2005), B358.

23) B.Maier and G.S.Frankel: J. Electrochem. Soc., 157(2010), C302.

24) T.Ishikawa, T.Yoshida, K.Kandori, T.Nakayama and S.Hara: Corros. Sci., 49(2007), 1468.

25) W.Thomson: Philos. Mag., 42(1871), 448

26) J.T.Keiser, C.W.Brown and R.H.Heidersbach: J. Electrochem. Soc., 129(1982), 2686

27) T.Misawa: Bull. Iron Steel Inst. Jpn., 6(2001), 325 (in Japanese). 